\title{
Ultraviolet Sterilization of Sugar Solution Containing Spores of Obligate Anaerobes Causing Flat Sour Spoilage
}

\author{
(A New Type of Flat Sour Spoilage. V)
}

(Received May 2, 1981)

\begin{abstract}
Akihiko NAKaYAMa and Rieko ShinYa
(Toyo Institute of Food Technology: 2-23-4 Minami Hanayashiki, Kawanishi City, Hyogo)

A sugar solution inoculated with the spores causing $O$. A. flat sour spoilage was sterilized by the use of a commercial ultraviolet (UV) sterilizer.

The concentration of the spores in the sugar solution $(45 \%)$ was decreased to $10^{-7}$ of the original level by treatment of the sugar solution in a continuous UV sterilizer at a flow rate of $500 \mathrm{~L} / \mathrm{hr}$, which corresponds to a UV dose of $10^{4} \mathrm{ergs} / \mathrm{mm}^{2}$. The UV dose required to reduce the number of survivors to one-tenth of the original population was $1500 \mathrm{ergs} / \mathrm{mm}^{2}$ in the present practical experiment using a commercial UV sterilizer, and this is in reasonably good agreement with the result obtained in the laboratory.

This work confirms that prior UV irradiation of sugar solutions is an effective countermeasure to prevent $\mathrm{O}$. A. flat sour spoilage of canned drinks kept hot in vending machines.
\end{abstract}

Key words: UV sterilization; sugar solution; flat sour spores; UV sterilizer; countermeasure to flat sour spoilage; canned drinks; hot vending

\section{Introduction}

In a previous paper ${ }^{1)}$, the authors reported that the ultraviolet (UV) resistance of the spores causing $O$. A. flat sour spoilage ${ }^{2)}$ is not especially high, in contrast to the high heat resistance, and that UV irradiation decreases the heat resistance of the spores at least to one-half. On the basis of these results, it was suggested that prior UV irradiation of sugar solutions can be employed as a countermeasure to prevent $O$. A. flat sour spoilage of canned drinks kept hot in vending machines.

This paper deals with a commercial application of this principle to the sterilization of canned drinks, including UV pretreatment of sugar solutions prior to use.

\section{Materials and Methods}

\section{Microorganisms}

Strain No. 24-1, which was isolated from spoiled canned coffee ${ }^{2)}$, was used throughout this work.

Preparation of Spore Suspension

The sporulation of the strain was achieved by the method described in the previous paper' ${ }^{2)}$.

The spores in $10 \mathrm{~L}$ of culture were harvested by centrifugation, washed three times with $300 \mathrm{ml}$ of sterilized deionized water, and suspended in $200 \mathrm{ml}$ of sterilized deionized water. The spore suspension was homogenized by using a Universal Homogenizer (Nihon Seiki Seisakusho Co., Ltd.) for $1 \mathrm{~min}$. These procedures were carried out at $0 \sim 4^{\circ} \mathrm{C}$. The spore suspension was heated in a boiling water bath for $30 \mathrm{~min}$ to destroy vegetative cells. The spore suspension thus obtained was stored in a refrigerator.

Preparation of Sugar Solution Containing the Spores

Two batches of sugar solution were prepared by dissolving $120 \mathrm{~kg}$ of granulated sugar in $147 \mathrm{~L}$ of water that had been treated with activated charcoal. The volume of each sug- 
ar solution was about $222 \mathrm{~L}$ and the Brix value was about $45 \%$.

One of the batches was used as a "blank"; $10 \mathrm{ml}$ of the spore suspension was inoculated into the other batch, to make a spore concentration of approximately $10^{4} / \mathrm{ml}$.

\section{$U V$ Irradiation and Sampling}

The UV sterilizer used was Steritron SF1NSM, $90 \mathrm{~W}$ (Chiyodakohan Co., Ltd.). A diagram of the UV sterilization procedure is shown in Fig. 1. A variable flow metering pump was used to regulate the flow rate of the sugar solutions to 170,250 or $500 \mathrm{~L} / \mathrm{hr}$, which, in the UV sterilizer, gave the sugar solutions UV doses of $3 \times 10^{4}, 2 \times 10^{4}$ and $1 \times$ $10^{4} \mathrm{ergs} / \mathrm{mm}^{2}$, respectively.

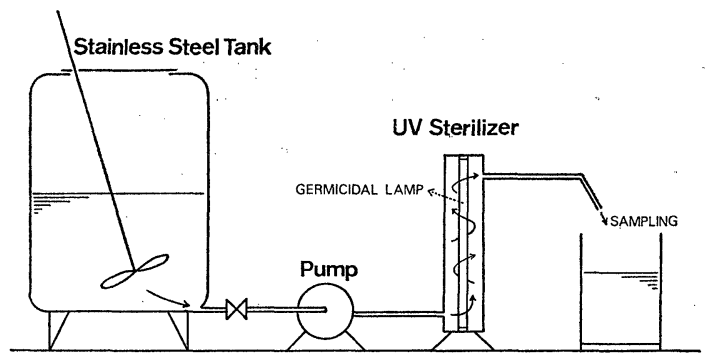

Fig. 1. Schematic diagram of the UV sterilization of sugar solutions

First, the "blank" sugar solution was allowed to flow for $10 \mathrm{~min}$ at each flow rate. Then, the sugar solution containing the spores was treated in the same way. Approximately $2 \mathrm{~L}$ samples of the sugar solutions were taken in sterile containers at the end of the flow rate perinds as irradiated samples.

Before these treatments, samples of approximately $2 \mathrm{~L}$ of the "blank" sugar solution and the sugar solution containing the spores were taken in sterile containers as nonirradiated samples.

\section{Determination of Survivors}

After heat treatment at $100^{\circ} \mathrm{C}$ for $10 \mathrm{~min}$, all the samples were inoculated into $\mathrm{mTGC}^{3)}$ as follows.

One hundred $\mathrm{ml}$ aliquots of each sample were inoculated into ten $1.5 \mathrm{~L}$ portions of mTGC, except for the non-irradiated sugar solution inoculated with the spores, for which the MPN method was used with mTGC.

\section{Identification of the Survivors}

To examine some principal characteristics of bacteria in the turbid mTGC media (except for those from the MPN method), $0.5 \mathrm{ml}$ aliquots of the turbid $\mathrm{mTGC}$ media were inoculated into $\mathrm{ISA}^{4)}, \mathrm{ISaA}^{5)}, \mathrm{TF}^{2)}, \mathrm{TSiF}^{2)}$ and $\mathrm{TSaF}^{2)}$, and $1.0 \mathrm{ml}$ aliquots of the turbid mTGC media were inoculated into DTA $^{6), 7)}$ and SMA $^{8)}$ by the pour-plate method. All these media were incubated at $55^{\circ} \mathrm{C}$ for 10 days.

\section{Results and Discussion}

The numbers of the mTGC media which became turbid are shown in Table 1.

In the case of the "blank" sugar solution with no UV irradiation, seven media out of 10 became turbid, and in the "blank" with irradiation at flow rates of 500 and $170 \mathrm{~L} / \mathrm{hr}$

Table 1. Detection of Bacteria with $1.5 \mathrm{~L} \mathrm{mTGC}$ Medium

\begin{tabular}{|c|c|c|c|c|c|c|c|c|c|c|}
\hline \multirow{3}{*}{$\begin{array}{c}\begin{array}{c}\text { Conditions of UV } \\
\text { irradiation }\end{array} \\
\text { No irradiation } \\
\text { (control) }\end{array}$} & \multicolumn{5}{|c|}{$\begin{array}{l}\text { Sugar solution } \\
\text { (blank) }\end{array}$} & \multicolumn{5}{|c|}{$\begin{array}{l}\text { Sugar solution with } \\
\text { the spores }\end{array}$} \\
\hline & $+{ }^{1 *}$ & $+2 *$ & $+3 *$ & $+4 *$ & $+{ }^{5 *}$ & & & $* *$ & & \\
\hline & $+6 *$ & $+^{7 *}$ & $-*$ & $-*$ & $-*$ & & & $T s$ & & \\
\hline Flow rate: $500 \mathrm{~L} / \mathrm{hr}$ & $+8 *$ & $-*$ & $-*$ & -* & $-*$ & $+{ }^{10 *}$ & $+11 *$ & $-*$ & $-*$ & -* \\
\hline$\left(1 \times 10^{4} \mathrm{ergs} / \mathrm{mm}^{2}\right)$ & $-*$ & $-^{*}$ & $-*$ & $-*$ & $-*$ & $-*$ & $-*$ & $-*$ & $-*$ & -* \\
\hline Flow rate: $250 \mathrm{~L} / \mathrm{hr}$ & $-*$ & -* & $-*$ & $-*$ & $-*$ & $+{ }^{12 *}$ & $+13 *$ & $-*$ & $-*$ & $-*$ \\
\hline$\left(2 \times 10^{4} \mathrm{ergs} / \mathrm{mm}^{2}\right)$ & $-*$ & $-*$ & $-*$ & $-*$ & $-*$ & $-*$ & $-*$ & $-*$ & $-*$ & $-*$ \\
\hline Flow rate: $170 \mathrm{~L} / \mathrm{hr}$ & $+{ }^{9 *}$ & -* & $-*$ & $-*$ & $-*$ & $+{ }^{14 *}$ & $-*$ & $-*$ & $-*$ & $-*$ \\
\hline$\left(3 \times 10^{4} \mathrm{ergs} / \mathrm{mm}^{2}\right)$ & $-*$ & $-*$ & -* & $-*$ & $-*$ & $-*$ & $-*$ & $-*$ & $-*$ & -* \\
\hline
\end{tabular}

* + , turbid; - , not turbid

The media which became turbid were numbered as in the table.

** Treated by the MPN method. 
Table 2. Identification Tests with the Turbid mTGC Media

\begin{tabular}{|c|c|c|c|c|c|c|c|}
\hline Medium No. ${ }^{a)}$ & ISA $\left.^{b}\right)$ & $\mathrm{ISaA}^{\mathrm{b})}$ & $\mathrm{TF}^{\mathrm{b})}$ & $\mathrm{TSiF}^{\mathrm{b})}$ & $\mathrm{TSaF}^{\mathrm{b})}$ & DTA $^{c)}$ & $\mathrm{SMA}^{\mathrm{c})}$ \\
\hline 1 & - & - & - & - & - & - & - \\
\hline 2 & + & + & + & + & + & - & - \\
\hline 3 & - & - & + & - & + & - & - \\
\hline 4 & + & - & - & + & - & - & - \\
\hline 5 & - & + & + & - & + & + & + \\
\hline 6 & + & - & - & + & - & - & - \\
\hline 7 & - & - & - & - & - & + & + \\
\hline 8 & - & - & - & + & - & - & - \\
\hline 9 & - & - & - & - & - & + & + \\
\hline 10 & + & - & - & + & - & - & - \\
\hline 11 & - & - & - & - & - & + & + \\
\hline 12 & - & - & - & + & - & - & - \\
\hline 13 & - & - & - & - & - & + & + \\
\hline 14 & + & - & - & + & - & - & - \\
\hline
\end{tabular}

one turbid medium out of 10 media was found in each case. No turbid media were found in the case of the treatment at $250 \mathrm{~L} / \mathrm{hr}$.

In the case of the sugar solution inoculated with the spores, irradiation at flow rates of 500 and $250 \mathrm{~L} / \mathrm{hr}$ gave two turbid media out of 10 , and one turbid medium out of 10 was found with the treatment at $170 \mathrm{~L} / \mathrm{hr}$.

The results of identification tests are shown in Table 2. The media which showed blackening of ISA or TSiF, but no blackening of TF, TSaF and ISaA, and gave no colonies on DTA and SMA, were media Nos. $4,6,8,10$, 12 and 14 . It is considered that Nos. 4, 6 and 8 became turbid due to the growth of contaminating microorganisms in the sugar that were similar to the bacteria used (strain No. 24-1), and that Nos. 10, 12 and 14 became turbid due to the growth of the bacteria used or similar microorganisms.

Table 3 shows the numbers of media in which turbidity was due to the growth of the bacteria used or similar microorganisms.

From the numbers of spores per $\mathrm{ml}$ estimated from Table 3 and by the MPN method, UV survival curves for these spores in the sugar solutions were obtained (Fig. 2). In the "blank" sugar solution used, the concentration of the spores of similar microorganisms was $2.23 \times 10^{-3} / \mathrm{ml}$. At $500 \mathrm{~L} / \mathrm{hr}$ flow rate, this value decreased to $1.05 \times 10^{-3} / \mathrm{ml}$, and at
Table 3. Numbers of Turbid Media Containing the Bacteria Used or Similar Microorganisms out of Ten mTGC Media Tested

\begin{tabular}{c|cc}
$\begin{array}{c}\text { Conditions of UV } \\
\text { irradiation }\end{array}$ & $\begin{array}{c}\text { Sugar } \\
\text { solution } \\
\text { (blank) }\end{array}$ & $\begin{array}{c}\text { Sugar } \\
\text { solution } \\
\text { with the } \\
\text { spores }\end{array}$ \\
\hline $\begin{array}{c}\text { No irradiation } \\
\text { (control) }\end{array}$ & 2 & $/$ \\
$\begin{array}{c}\text { Flow rate: } 500 \mathrm{~L} / \mathrm{hr} \\
\left(1 \times 10^{4} \mathrm{ergs} / \mathrm{mm}^{2}\right)\end{array}$ & 1 & 1 \\
$\begin{array}{c}\text { Flow rate: } 250 \mathrm{~L} / \mathrm{hr} \\
\left(2 \times 10^{4} \mathrm{ergs} / \mathrm{mm}^{2}\right)\end{array}$ & 0 & 1 \\
$\begin{array}{c}\text { Flow rate: } 170 \mathrm{~L} / \mathrm{hr} \\
\left(3 \times 10^{4} \mathrm{ergs} / \mathrm{mm}^{2}\right)\end{array}$ & 0 & 1
\end{tabular}

the other two flow rates, the values were below $1.05 \times 10^{-3} / \mathrm{ml}$.

On the other hand, after the treatment of the sugar solution containing the spores at all the flow rates $(500,250$ and $170 \mathrm{~L} / \mathrm{hr})$ the concentration of surviving spores was $1.05 \times 10^{-3} / \mathrm{ml}$, which is smaller than the original $\left(2.30 \times 10^{4} /\right.$ $\mathrm{ml}$ ) by a factor of approximately $10^{-7}$. The reason why the same values were obtained at all the flow rates is unknown. However, at the fastest flow rate $(500 \mathrm{~L} / \mathrm{hr})$ the UV dose was $1 \times 10^{4} \mathrm{ergs} / \mathrm{mm}^{2}$. Division of the latter by the $D$ value for UV of this strain $(1500$ ergs $\left./ \mathrm{mm}^{2}\right)^{1)}$ gives 6.7 , which is consistent with the decrease of the concentration of the spores to $10^{-7}$ in the sugar solution.

It seems safe to say that at $500 \mathrm{~L} / \mathrm{hr}$ flow 


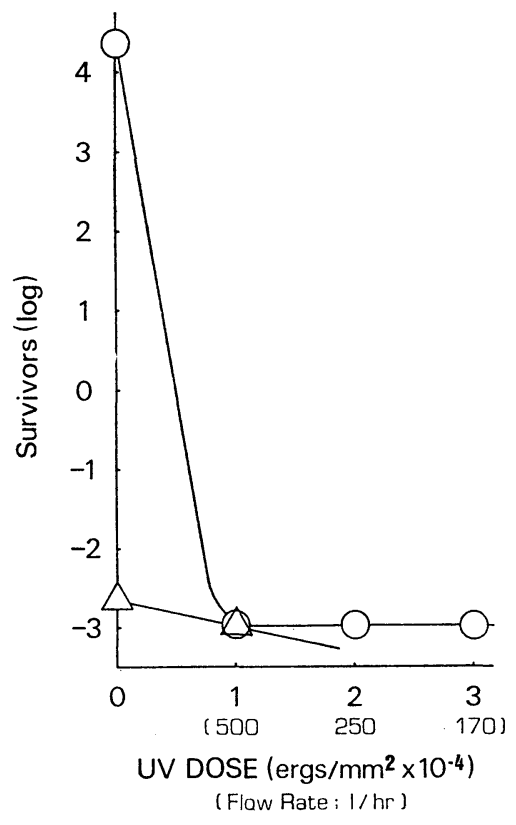

Fig. 2. UV survival curves for spores of strain No. 24-1 in sugar solution after treatment with the UV sterilizer

$-\triangle-$, blank; -O-, strain No. 24-1

rate (UV dose of $1 \times 10^{4} \mathrm{ergs} / \mathrm{mm}^{2}$ ) the concentration of the spores of strain No. 24-1, one of the bacteria causing $O$. A. flat sour spoilage, can be reduced by a factor of $10^{-7}$ compared to the original level in $45 \%$ sugar solution by the use of a commercial UV sterilizer. Moreover, it has been established by the authors that UV irradiation decreases the heat resistance of the spores to one-half ${ }^{11}$.

Therefore, in view of the laboratory results ${ }^{1)}$, it seems clear that prior UV sterilization of sugar solutions can be employed as a countermeasure to prevent $\mathrm{O}$. A. flat sour spoilage of canned drinks which are often kept hot in vending machines in Japan.

\section{Acknowledgement}

The authors wish to express their thanks of Prof. Hajime Kadota, Faculty of Agriculture, Kyoto University, for many helpful discussions and suggestions throughout this study. Thanks are also due to Prof. Shigeru Otsuka, Toyo Junior College of Food Technology, for many discussions.

This study was supported in part by a scientific research grant from the Ministry of Health and Welfare.

A part of this paper was presented at the annual meeting of the Japan. Soc. Sci. Fish. on Oct. 5, 1979, in Hakodate.

\section{References}

1) Nakayama, A., Shinya, R.: J. Food Hyg. Soc. Japan, 22, 415 420 (1981).

2) Nakayama, A., Samo, S.: Bull. Japan. Soc. Sci. Fish., 46, 1117 1123 (1980).

3) Sakazaki, R.: Bacterial Culture Media, Part I, p. 277 278 (1978), Kindai Shuppan, Tokyo.

4) Cameron, E. J.: J. Ass. Off. Agric. Chem., 21, 452 454 (1938).

5) Nakayama, A., Shinya, R.: J. Food Hyg. Soc. Japan, 22, 30 36 (1981).

6) Williams, O. B.: Food Res., 1, 217 221 (1936).

7) National Canners Association Research Labo. ratories: "Laboratory Manual for Food Canners and Processors, 3rd ed." Vol. 1, p. 13 14 (1968), The Avi Pub. Co., Westport, Connecti. cut.

8) American Public Health Association: "Standard Methods for the Examination of Dairy Products, 14th ed." p. 67 68 (1978), American Public Health Association, New York. 